\title{
Sosyal Bilgiler Öğretmen Adaylarının Sözlü Tarih Çalışmasından Edindikleri Kazanımlara İliş̧kin Görüșlerinin İncelenmesi
}

\section{An Investigation of Social Studies Teacher Candidates' Opinions Regarding Their Achievements from Oral History Activity}

\author{
Hülya GÖLGESIZZ GEDIKKLER ${ }^{l}$
}

${ }^{1}$ Dr. Öğr. Üyesi, Türkçe ve Sosyal Bilimler Eğitimi Bölümü, Eğitim Fakültesi, Ege Üniversitesi, Türkiye, hulya.golgesiz.gedikler@ege.edu.tr, (https://orcid.org/0000-0003-0843-7883)

Geliș Tarihi: 18/11/2020

Kabul Tarihi:22/02/2021

\section{ÖZ}

$\mathrm{Bu}$ araştırmanın amacı, Sosyal Bilgiler Öğretiminde Tarihsel Kanıt, Yerel ve Sözlü Tarih dersi kapsamında gerçekleştirilen örnek bir sözlü tarih uygulamasının kazanımlarına ilişkin sosyal bilgiler öğretmen adaylarının görüşlerini incelemektir. Nitel araştırma desenlerinden bütüncül tek durum çalışmasının kullandığı bu araştırmada çalışma grubunu Ege Üniversitesi Eğitim Fakültesi Sosyal Bilgiler Öğretmenliği Anabilim Dalı'nda 2019 -2020 öğretim yılında araştırmacının yürüttüğü dersi alan 18 öğretmen adayı oluşturmaktadır. Araştırma verileri öğretmen adaylarının ortaya koydukları ürünler, çalışma sürecinde tuttukları günlükler ve yarı yapılandırılmış görüşme formuyla gerçekleştirilen odak grup görüşmelerinden elde edilmiş, verilerin değerlendirilmesi ve yorumlanmasında içerik analizi uygulanmıştır. Araştırma bulguları, öğretmen adaylarının gerçekleștirdiğgi sözlü tarih çalışmasıyla önemli kazanımlar sağladığını ve sözlü tarih yönteminin tarih konularının öğretiminde güçlü bir etkiye sahip olduğunu ortaya koymuştur. Bulgular doğrultusunda lisans eğitiminde sosyal bilgiler öğretmen adaylarına sözlü tarih çalışmalarını deneyimlemeleri için daha çok firsat sunulması gerektiği önerisinde bulunulmuştur.

Anahtar Kelimeler: Sözlü tarih, sosyal bilgiler eğitimi, tarih eğitimi, öğretmen eğitiminde yeni yaklaşımlar.

\begin{abstract}
The aim of this research was to examine the views of social studies teacher candidates as regards to the objectives of a model oral history activity carried out within the scope of the course. The research used a holistic single-case study design and a qualitative research pattern. The study group was composed of 18 teacher candidates, who took the course taught by the researcher in the 2019-2020 academic year at the Department of Social Studies Teaching, Faculty of Education, Ege University. The research data was obtained from the materials generated by the teacher candidates, the diaries they kept during the study process, and the focus group interviews conducted with a semi-structured interview form. Content analysis was applied in the evaluation and interpretation of the data. The research findings revealed that teacher candidates acquired significant objectives through oral history studies and that the oral history method had a strong impact on the teaching of historical topics.
\end{abstract}

Keywords: Oral history, social studies education, history education, new approaches in teacher education. 


\section{GİRIŞ}

Sosyal bilimler alanlarından seçilmiş bilgilerin disiplinlerarası bir yaklaşımla ilköğretim dönemi çocuklarının düzeyine uygun olarak verildiği bir öğretim programı olan sosyal bilgiler, ilk olarak 20. yüzyıl başında ABD'de okul programlarına girmiş ve bugün Türkiye'nin de içinde bulunduğu bazı devletlerin eğitim programlarında (Safran, 2015) yerini ve önemini korumaktadır. Sosyal bilgiler eğitiminin içeriği ve amacına ilişkin farklı bakış açıları bulunmaktadır. $\mathrm{Bu}$ farklılaşmada bilim insanlarının pedagojik yaklaşımları ve devletlerin ideolojilerinin yanı sıra çağın gereklilikleri de belirleyici olabilmektedir. Ross, Mathison ve Vinson (2014) sosyal bilgilerin amacının gençleri topluma etkin katılım için gereken bilgi, değer ve becerilere sahip olacak şekilde hazırlamak olduğu konusunda bir görüş birliğinden söz etmektedir. Çok genel bir yaklaşımla Blanchard, Senesh ve Patterson-Black (1999) sosyal bilgiler eğitimini bir toplumun gençlerinin kendilerini dünyaya yerleştirmeyi öğrendikleri disiplinlerin ve fikirlerin yaşamsal olarak yapılandırmasını kapsayan alan olarak tanımlamaktadır. Sosyal bilgiler öğretiminin içeriği ve amaçları çağın gereklerine göre yenilenmekte ve daha çok beceri temelli olması önemsenmektedir. Ancak bugün için dersin öğretiminde ağırlıklı olarak geleneksel yöntemlerin sürdürülüyor olması önemli bir sorun olarak görülmektedir. Sosyal bilgiler öğretiminin öğretmen merkezli ve ders kitabı odaklı yürütüldüğü, öğrencilerin dersi sıkıcı bulduğu ve ilgisiz kaldığı gibi pek çok sorun çeşitli araştırmalarda ortaya koyulmaktadır (Açıkalın, 2018; Busby, 2011; Crocco, 1998; Çelikkaya ve Kuş, 2009; Foster ve Padgett, 1999; Kaya ve Güven, 2012; Şimşek ve Kaymakç1, 2015). Eğitimde öğrenci merkezli, uygulamaya dayalı ve beceri temelli yaklaşımların öneminin artmasıyla birlikte zamanla sözlü tarihin sosyal bilgiler ve tarih derslerinde bir öğretim yöntemi olarak kullanılabileceği anlaşılmış ve sözlü tarih pek çok devletin öğretim programlarına girmiştir.

Sözlü tarih çalışması bir konu çerçevesinde belirlenen kaynak kişilerle yapılan uzun söyleşiler sonucu ortaya çıkan bilgileri belli bir sistem içerisinde değerlendirmeyi ve incelemeyi ifade etmektedir (Öztürkmen, 2002). Diğer yandan pek çok araştırmacı (Welton ve Mallan, 1988; Somersan, 1998; Kyvig ve Marty, 2000; Stradling, 2003; Busby, 2011; Richtie, 2015), sözlü tarihi tarihsel öneme sahip olan konulara ilişkin görüşmeler yoluyla kaynak kişilerin anılarını derlemeye ve kaydetmeye dayalı bir araştırma yöntemi olarak tanımlamaktadır. Caunce (2017), sözlü kaynakların tarihçilerin dayandıkları yazılı belgeleri tamamlama ve alternatif bir tarih oluşturma özelliğinden söz etmektedir. Sözlü tarih yönteminin eğitimde kullanılmasının çeşitli yararlar sağladığını ortaya koyan çalışmalar bulunmaktadır (Açıkalın, 2018; Dayton-Wood, Hammonds, Matherson ve Tollison, 2012; Demircioğlu, 2007; Dere, 2018; Dere, 2019; Dere ve Alkaya, 2017; Dere ve Dinç, 2018; Sarı, 2007; Doğan, 2015; Dutt-Doner, Allen ve Campanaroa, 2016; Kabapınar ve İncegül, 2016; Lattimer ve Kelly, 2013; Metin ve Öz, 2019). Öncelikli olarak sözlü tarih hem öğretmen adayları hem de öğrenciler için tarihsel içerik bilgisini arttırmada ve tarihsel anlayışı geliştirmede etkili bir öğretim yöntemidir (Busby, 2011).

Türkiye'de sosyal bilgiler öğretiminin içeriğinde tarih konularının önemli bir ağırlık oluşturduğu ve uzun bir dönemi kapsadığı bilinmektedir. Küçük yaş gruplarına sunulan bu tarih bilgilerininin zamana yerleştirilmesini, zihinlerde canlandırılmasını, gelişmelerin dönemin koşullarına göre anlamlandırılmasını ve günümüzü anlamaya katkı sağlamasını başarmak özel bir çaba gerektirmektedir. Alan yazında bu durum tarihsel düşünme becerileri olarak ifade edilmektedir. Dilek (2002) tarihi anlamak, geçmiş hakkında yorumlar yapmak ve geçmişle güncel arasında köprüler kurmak açısından öğrencilerde tarihsel düşünmenin geliştirilmesi gerektiğini belirtmektedir. Ng-A-Fook ve Smith'e (2017) göre tarihsel düşünme, öğrencilerin geçmişle ilgili varsayımları yeniden düşünmeye, hem bugünü hem de geleceği yeniden tasarlamaya zorlandığı bir süreçtir. Tarihsel düşünme becerileri olayların sıralanması, örüntülerin analizi ve anlamın oluşturulmasına yardımcı olmak için olayların bağlam içine yerleştirilmesini içermektedir. Dolayısıyla genç kuşakların tarih öğrenmeleri ve tarihsel bilinç 
kazanmaları için aktif olarak geçmişin izini sürmeleri önemlidir. William Wheeler ve Susan Becker'e (1986) göre sözlü tarih, dikkatli ve mantıklı bir şekilde diğer kaynaklarla birlikte kullanıldı̆̆ında, geçmişin duygusunu yeniden yaratmaya yardımcı olacak paha biçilmez bir araçtır (akt. Whitman, 2000). Sözlü tarih aynı zamanda vatandaşlık duygusunu geliştiren bir araç olarak da kullanılabilir. Öğrenciyi daha geniş toplumsal konulara ilgi duymaya teşvik eder, entelektüel anlamda onları destekler ve bu ilgilerini daha sosyal ve kültürlerarası beceri ve konulara yöneltmelerini sağlar (Dutt-Donera vd, 2016).

Tarihsel anlayışının yanı sıra önemli öğrenme becerilerini geliştirmede güçlü bir pedagojik araç olan sözlü tarih öğrenciyi ders kitaplarından biraz olsun uzaklaştırarak insanlarla görüşmesini, görüşmelerde elde edilen bilgileri işleyerek ve analiz ederek kendi bilgisini oluşturmasını sağlar. Aynı zamanda farklı öğrenme düzeylerine sahip öğrenciler için uygun bir çalışmadır (Richtie, 2015). Sözlü tarih çalışmalarının yalnızca okuma becerilerine odaklanmayarak sözlü ve etkileşimli becerileri gerektirecek öğrenme yöntemlerini içermesi, öğrencilerin farklı öğrenme stillerinin karşılamasına olanak sağlamaktadır (Crocco, 1998). Sosyal bilgiler dersinde gerçekleştirilecek bir sözlü tarih çalışmasında öğrenci tasarlama, çalışma planı hazırlama, araştırma yapma, görüşme yapma, görüşmelerden elde edilen bilgilerin analizini yapma, yazıya geçirme ve sunma gibi süreçleri izler. Böyle bir çalışma öncelikle öğrencilerin grupla çalışma ve iletişim becerilerini geliştirir. Bunun yanı sıra gözlem, karşılaştırma ve çıkarım yapma gibi düşünme becerilerini de geliştirir. Ayrıca Dere'nin (2018) de belirttiği gibi öğrenci, bağımsız şekilde öğrenme ve araştırma yapma, uygun yöntemleri eleştirel biçimde kullanma (materyal toplama, düzenleme, işleme ve raporlama) yeteneklerini geliştirme olanağı bulur.

Türkiye'de yapılandırmacı eğitim yaklaşımının benimsenmesiyle birlikte ilk olarak 2005-2006 öğretim y1lında uygulanan sosyal bilgiler öğretimi programında sözlü tarih etkinliklerine yer verilmiştir (MEB, 2005). 2018'de yürülüğe giren sosyal bilgiler öğretim programında dördüncü sınıftan itibaren sözlü tarih çalışmaları başlatılmakta ve program uygulama önerisi kapsamında uygun konularda sözlü tarih çalışmalarına yer verilmesi gerektiği belirtilmektedir (MEB, 2018). Sözlü tarih çalışmalarının tarihsel konuların öğretiminde büyük yararlar sağlamanın yanı sıra program çerçevesinde öğrenciye kazandırılması düşünülen araştırma, empati, eleştirel düşünme, gözlem, iletişim, işbirliği, değişim ve sürekliliği algılama, kanıt kullanma, karar verme, problem çözme, zaman ve kronolojiyi algılama gibi pek çok beceriyi geliştirdiği yukarıda belirtilen araştırmalarla ortaya konmuştur. Ancak mevcut araştırmalarda görüldüğü gibi bu konuda temel sorun, öğretmenlerin pek çok yeni öğretim yöntem ve yaklaşımı gibi sözlü tarihi de sınıflarında çok kullanmamalarıdır. Çelikkaya ve Kuş'un (2009) araştırması öğretmenlerin geleneksel yöntem ve tekniklerin dışına pek fazla çıkamadığını göstermektedir. Kaya ve Güven'in (2012) araştırmasında, sınıfta yapılandırmacılığın izlerinin çok zayıf olduğu ve yeni programın öngördüğü şekilde öğrencileri etkin kılacak yöntemlerin oldukça sinırlı kullanıldığ belirtilmektedir. Mutluer (2013) sosyal bilgiler öğretmenlerinin programda yer alan temel becerileri derslerde nasıl öğretecekleri konusunda bilgi eksikleri olduğunu savunmaktadır.

Sözlü tarih çalışması yürütmek bilgi sahibi olmanın yanı sıra deneyim gerektirmektedir. Dolayısıyla lisans eğitiminde kazanılacak bilgi ve deneyimlerin öğretmen adaylarının öğretmenlik yaşamına olumlu bir yansımasının olacağı düşünülmektedir. Nitekim Akbaba ve Kılcan'ın (2014) çalışmasında bu düşünceyi destekleyen bulgulara ulaşılmıştır. Amerikalı eğitimci Busby (2011), öğretmen adaylarının çok azının öğretmen eğitimi ya da önceki eğitim geçmişlerinde sözlü tarihi deneyimlediklerini belirtmiştir. Öğretmen eğitiminde sözlü tarih çalışmalarını önemseyen Whitman (2000), öğretmen adaylarının örnek öğretim stratejilerine maruz kalmamasının alana olumsuz yansımalarından söz etmekte ve özellikle tarihsel sorgulamayı deneyimlemeleri için onlara firsatlar sağlamak gerektiğini savunmaktadır. Dündar (2017) ile Beldağ ve Balcı'nın (2017) çalışmaları sözlü tarih yönteminin öğretmen ve 
öğretmen adayları tarafından yeterince deneyimlenmediği ve nasıl uygulanacağına ilişkin bilgi sahibi olmadıklarını ortaya koymaktadır.

Türkiye'de son zamanlarda öğretmen adaylarıyla yapılan sözlü tarih çalışmaları artmaya başlamıştır (Akbaba ve Kılcan 2014; Aktın ve Tekir, 2018; Çelik, 2018; Demircioğlu, 2016; Dere, 2018; Doğan, 2015; Sarı ve Türküresin, 2018). Ancak lisans eğitimi düzeyinde daha çok sözlü tarih çalışmasının yapılmasına ihtiyaç duyulduğu da bir gerçektir. Yakın zamana kadar az sayıda eğitim fakültesinde lisans düzeyinde seçmeli olarak sözlü tarih derslerine yer verildiği bilinmektedir. 2018-2019 eğitim öğretim yılında uygulamaya koyulan sosyal bilgiler öğretmenliği lisans programında yer alan Sosyal Bilgiler Öğretiminde Tarihsel Kanıt, Yerel ve Sözlü Tarih dersi (Yüksek Öğretim Kurumu, 2018) sosyal bilgiler derslerinde kanıt kullanma, yerel tarih ve sözlü tarih projeleri yürütme konusunda öğretmen adaylarının bilgi ve becerilerini geliştireceği gibi onlara uzun süreli çalışmalarda yer alma olanağı da sunmaktadır. Öğretmen adaylarının sözlü tarih çalışması uygulama sürecini ve kazanımlarını bizzat deneyimlemelerinin öğretmenlik yaşamlarına da olumlu yansımaları olacağı düşüncesiyle belirtilen ders kapsamında örnek bir sözlü tarih uygulaması gerçekleştirilmiştir. Çalışmanın bulgularının sözlü tarih alan yazınına önemli katkılar sağlaması beklenmektedir.

Bu araştırmanın amacı Sosyal Bilgiler Öğretiminde Tarihsel Kanıt, Yerel ve Sözlü Tarih dersi kapsamında gerçekleştirilen örnek bir sözlü tarih uygulamasının kazanımlarına ilişkin sosyal bilgiler öğretmen adaylarının görüşlerini incelemektir. Buradan hareketle aşağıdaki sorulara yanıtlar aranmıştır:

1. Sosyal bilgiler öğretmen adaylarının sözlü tarih uygulamasından edindikleri genel kazanımlara ilişkin görüşleri nelerdir?

2. Sosyal bilgiler öğretmen adaylarının sözlü tarih uygulamasının tarihsel öğrenme ve tarihsel düşünmeye etkisine ilişkin görüşleri nelerdir?

\section{YÖNTEM}

\subsection{Araştırma Deseni}

$\mathrm{Bu}$ çalışmada nitel araştırma desenlerinden durum çalışması deseni kullanılmıştır. Durum çalışması, araştırmacının belirli zaman içerisinde sınırlandırılmış bir ya da birkaç durumu gözlem, görüşme, görsel- işitsel materyaller, dokümanlar gibi çoklu veri kaynakları aracılığıyla derinlemesine incelediği bir araştırma yaklaşımıdır (Creswell, 2016). Bu çalışma desenin seçilmesinin nedeni, durumu kendi akışı içerisinde derinlemesine ve etraflı bir biçimde betimlemenin amaçlanmış olmasıdır. Tek bir analiz biriminin incelendiği bütüncül tek durum çalışması (Yin, 2014) tercih edilmiştir. Çeşitli durumlarda kullanılabilen bütüncül tek durum desenleri iyi formüle edilmiş bir kuramın teyit edilmesi ve çürütülmesi amacıyla da kullanılabilir (Yıldırım ve Türker, 2018). Bu çalışmada bütüncül tek durum deseninin seçilmesinin amacı dünya genelinde eğitim alanında önemli katkılar sağladığı pek çok araştırma ile ortaya koyulan sözlü tarih çalışmasının öğretmen adayları üzerindeki katkılarını belirlemektir. Aanaliz birimini Ege Üniversitesi, Eğitim Fakültesi Sosyal Bilgiler Öğretmenliği lisans programında öğrenim gören 18 öğretmen adayının sözlü tarih uygulamasının kazanımları oluşturmaktadır. Çalışılan durum, 2018 Sosyal Bilgiler Öğretmenliği Lisans Programı doğrultusunda 2019-2020 yılında kurumda ilk kez açılmış, seçmeli bir alan dersi olan Sosyal Bilgiler Öğretiminde Tarihsel Kanıt, Yerel ve Sözlü Tarih dersi programı kapsamında gerçekleştirilen sözlü tarih çalışmasıdır. Daha önce benzer bir ders almamış olan katılımcılar, projenin araştırma konusu olan 1970'ler dönemi hakkında birinci sınıfta İnkılap Tarihi ve Atatürkçülük dersinde bilgi sahibi olmuşlardır. 


\subsection{Katılımcilar}

Çalışma grubunun oluşturulmasında nitel araştırmalarda derinlemesine araştırma yapabilme olanağı sağlayan "amaçlı örnekleme" yöntemlerinden biri olan "ölçüt örnekleme" kullanılmıştır. $\mathrm{Bu}$ yöntemde örneklemin problemle ilgili olarak belirlenen niteliklere sahip kişiler, olaylar ya da durumlardan oluşması gerekmektedir (Büyüköztürk, Kılıç-Çakmak, Akgün, Karadeniz ve Demirel, 2020). Katılımcıların belirlenmesinde Sosyal Bilgiler Ögretiminde Tarihsel Kanıt, Yerel ve Sözlü Tarih dersini seçme ve düzenli devam ediyor olma ölçütü dikkate alınmıştır. Bu doğrultuda Çalışma grubunu 2019 -2020 öğretim yılında Ege Üniversitesi Eğitim Fakültesi Sosyal Bilgiler Öğretmenliği Anabilim Dalı'nın 2. sınıfında okuyan ve araştırmacının yürüttüğü dersi alan 13'ü kadın ve 5'i erkek olmak üzere toplam 18 öğretmen adayı oluşturmaktadır. Katılımcılar 20-22 yaş aralığındadır. Sadece bir öğretmen adayı ögrenim hayatında görüşme yapmayı gerektiren fakat sözlü tarih olmayan bir projede yer almıştır.

\subsection{Etik Konular}

Öğretmen adayları uygulama öncesinde araştırma ile ilgili bilgilendirilmiştir. Ders kapsamında elde edilecek sözlü tarih çalışması verilerinin bilimsel amaçlı bir araştırmada kullanılmasını kabul eden öğretmen adayları günlük yazma ve odak grup görüşmelerine katılma konusunda gönüllü olmuşlar ve onam formu imzalamışlardır. Aynı zamanda öğretmen adaylarının sözlü tarih görüşmesi yaptığı kaynak kişiler vermiş oldukları bilgilerin telif hakkının devrine ilişkin onam formu imzalamışlardır. Çalışmaya Ege Üniversitesi Bilimsel Araştırma ve Yayın Etiği Kurulu tarafından 28.11.2019 tarih ve 453 nolu protokol ile onay verilmiştir. Araştırma etiği gereğince öğretmen adaylarının adları kullanılmayarak her biri Ö1, Ö2, Ö3... şeklinde; proje kapsamında oluşturulan çalışma grupları da 1.grup, 2. grup, 3. grup şeklinde ifade edilmiştir.

\subsection{Veri Toplama Araçları}

$\mathrm{Bu}$ çalışmada birden fazla veri toplama aracı işe koşularak zengin ve birbirini teyit edecek veri çeşitliliğine ulaşmak amaçlanmıştır. Katılımcıların çalışma kapsamında hazırladıkları proje raporları, süreçteki deneyimlerini ve düşünceleri kaydettikleri günlükler ve odak grup görüşmelerinde kullanılan yarı yapılandırılmış görüşme formu veri toplama araçları olarak kullanılmıştır.

Proje raporları: Üçerli gruplar halinde sözlü tarih çalışması yapan katılımcıların çalışmanın sonunda oluşturdukları grup raporlardır. Bu raporların sonuç bölümünde yer alan bilgiler (araştırılan dönemin analizi, geçmiş ile günümüzün karşılaştırması, sözlü tarih çalışmasının kazanımları) araştırmaya veri sağlamak amacıyla değerlendirilmiştir.

Katılımc1 günlükleri: Her öğretmen adayı 6 haftalık uygulama sürecinde bireysel olarak günlük tutmuştur. Öğretmen adaylarından sözlü tarih çalışması yaptıkları günlerde yaşadıkları deneyimleri, çalışmalar hakkındaki düşüncelerini ve duygularını defterlere kaydetmeleri istenmiştir.

Yarı yapılandırılmış görüşme formu: Odak grup görüşmelerinde kullanılmıştır. Alan yazın taraması doğrultusunda araştırmacı tarafından hazırlanmış ve iki alan uzmanının görüşlerinden yararlanılmıştır. Görüşme formunda "Sözlü tarih çalışmasının tarih konularının öğrenilmesine etkisi hakkında ne düşünüyorsunuz?", "Sözlü tarih çalışmasının sosyal bilgiler öğretim programındaki hangi becerileri desteklediğini düşünüyorsunuz?", "Gerçekleştirdiğiniz sözlü tarih çalışmasının size ne tür kazanımlar sağladığını düşünyorsunuz?"gibi sorulara yer verilmiştir.

\subsection{Veri Toplama Süreci}

Çalışma kapsamında, dersin içeriğini desteklemesi ve aynı zamanda bir yerel tarih araştırması olması açısından öğretmen adaylarından "1970'li Yıllarda Ege Üniversiteli Olmak" 
temalı bir sözlü tarih çalışması yapmaları istenmiştir. Uygulamada belirli bir tarihsel döneme odaklanılmasının nedeni öğretmen adaylarının daha önce farklı șekillerde öğrenmiş oldukları bu dönemi, sözlü tarih yaklaşımı ile birincil sözlü kaynaklardan öğrenmenin kazanımlarını fark edebilmelerini sağlamaktır. Tarihsel düşünmeye ilişkin bazı sosyal bilgiler öğretimi becerileri konusunda farkındalık geliştirmeye elverişli olacağı düşüncesiyle özellikle öğrenim gördükleri üniversitenin öğrencilik yaşamı ekseninde dönemi incelemeleri tercih edilmiştir. Uygulama kapsamında 18 öğretmen adayının sözlü tarih projesini gönüllü olarak oluşturdukları üçer kişilik gruplar halinde yürütmeleri ve 1970'li yıllarda Ege Üniversitesi'nde öğrenim görmüş en az 4 kişi ile sözlü tarih görüşmesi yapmaları istenmiş ve her grup üyesinin en az bir sözlü tarih görüşmesini kendisinin yürütmesi gerektiği belirtilmiştir. Çeşitli çalışmalardan yararlanılarak ve çoğunlukla Sözlü Tarih Derneği'nin (OHA, 2014) ilkeleri esas alınarak araştırmacı tarafından hazırlanan sözlü tarih uygulama rehberi öğretmen adayları ile önceden paylaşılmıştır. Bu proje kapsamında öğretmen adaylarının sorumlukları; konu hakkında ön araştırma yapmaları, görüşecekleri kaynak kişilere kendi olanakları ile ulaşarak görüşmelerini gerçekleştirmeleri, görüşmeleri kaydetmeleri ve arşivlemeye uygun olarak etiketlenmeleri, görüşme kayıtlarını deşifre ederek yazıya geçirmeleri, görüşme yaptıkları kişilerden kanıt niteliği taşıyan tarihsel materyal sağlamaları ve çalışmalarını bir rapor halinde sunmalarıdır. Proje raporlarında sözlü tarih yaklaşımı hakkında bilgi verilmesi, çalışma planı ve proje sürecindeki deneyimlerin aktarılması, kaynak kişilerin anlatımları ile diğer kaynaklardan sentezlenen bilgilerle 1970'li yıllardaki üniversite yaşamı hakkında bilgi verilmesi ve dönemin günümüzle karşılaştırılması istenmiştir. Öğretmen adaylarının proje raporunda sözlü tarih çalışmasının sağladığı katkılara ilişkin çıkarım yapmaları da istenmiştir. Öğretmen adaylarının sözlü tarih projesi ile ilgili ortaya koydukları ürünler ders kapsamında önceden belirlenen ölçütler doğrultusunda değerlendirilmiştir. Öğretmen adaylarının tamamı çalışmalarını başarılı bir şekilde tamamlanmış ancak sözlü tarih performansları ve çalışma deneyimleri araştırmaya dâhil edilmemiştir. Öğretmen adaylarından çalışma sürecindeki deneyimlerini, düşüncelerini ve duygularını kendilerine verilen defterlere günlük tarzında kaydetmeleri istenmiştir. Katılımcılardan 17'si günlüğünü araştırmacıya teslim etmiş, 1 katılımcı teslim etmemiştir. Sözlü tarih çalışmasının ürünlerinin tesliminden sonra katılımcıların tamamıyla iki grup halinde odak grup görüşmeleri yapılmıştır. Patton'a (2018) göre odak grup görüşmeleri zaman ve emekte tasarruf sağlamas1 bakımından maliyet kolaylığı sağlamanın yanı sıra katılımcılar arasındaki etkileşimler aracılığıyla veri kalitesini artırabilmektedir. Bu çalışmada odak grup görüşmeleri aynı zamanda bir proje değerlendirme toplantıs1 olarak düşünüldüğü ve katılımcılar aras1 etkileşim önemsendiği için tercih edilmiştir. Görüşmelerde katılımcılar 9'ar kişilik iki gruba ayrılmış, odak gruplar sözlü tarih çalışma grubu üyelerinin en az birinin diğer grupta bulunması gözetilerek oluşturulmuştur. Görüşmelerin biri 1 saat 36 dakika, diğeri 1 saat 48 dakika sürmüş ve görüşmeler kaydedilmiştir. Araştırmanın veri toplama aşaması 8 haftalık bir süreyi kapsayacak şekilde aşağıdaki gibi planlanmıştır:

1. Hafta: Sözlü tarihle tanışma, sözlü tarih görüşmesinin nasıl yapılacağının açıklanması, proje konusu hakkında bilgilendirme ve proje kapsamındaki sorumlulukların açıklanması,

2. Hafta: Sözlü tarih çalışma örneklerini incelemesi; sınıf içinde sözlü tarih görüşme uygulamalarının gerçekleştirilmesi; sonraki hafta araştırma konusu hakkında ön araştırma yapılması, örnek sorular hazırlanması ve görüşme yapılacak kaynak kişilerle ilgili araştırma başlatılması için bilgilendirmenin yapılması ve günlük yazma esaslarının açıklanarak ilgili defterlerin dağıtılması,

3. Hafta: Sözlü tarih görüşme rehberinin paylaşılması; konu hakkında yapılan ön araştırma ve hazırlanan görüşme sorularının paylaşılarak tartışılması; her grubun kullanabileceği ortak bir soru çerçevesi belirleme; görüşmelerin transkripsiyonu, analizi ve rapor yazma hakkında bilgilendirme, 
4-6 Haftalar: Görüşmelerin yapılması ve deşifre edilmesi, görüşmeler ve transkriptlerin teslim edilmesi, eş zamanlı olarak tamamlanan görüşmelerin ve transkriptlerin değerlendirilmesi,

7. Hafta: Proje raporlarının hazırlanması ve teslim edilmesi. Sözlü tarih ürünlerinin (görüşme kayıtları, transkriptler, raporlar ve tarihsel materyaller) değerlendirilmesi,

8. Hafta: Odak grup görüşmelerinin yapılması.

\subsection{Verilerin Analizi}

Verilerin analizinde içerik analizi uygulanmıştır. İçerik analizi ile veriler daha derin bir işleme tabi tutulur, betimsel bir yaklaşlımla farkedilmeyen kavram ve temalar bu analiz sonucu keşfedilir (Yıldırım ve Şimşek, 2018). İçerik analizinde çözümleme yapılırken odak grup görüşmelerinin kayıtları deşifre edilerek araştırma soruları ile ilgili veriler kodlanmış, kodlar yeniden okumalarla netleştirilmiş ve bir kod listesi oluşturulmuştur. Kod listesi diğer odak grup görüşmesine uygulanmış ve revize edilmiştir. Görüşmelerde elde edilen kodlar belirli temalar altında toplanmıştır. Proje raporları ve günlüklerden elde edilen veriler oluşturulan kod ve temalarla ilişkilendirilmiştir. Veri kaynaklarının tamamı dikkate alınarak kodların kaç katılımcı tarafından ifade edildiği saptanmış, temalar, kodlar ve ifade edilme sayısı tablolar halinde gösterilmiştir. Raporlaştırma aşamasında durumu olduğu gibi gösterebilmek amacıyla doğrudan alıntılara yer verilmiştir. Alıntılamada farklı veri kaynakları ve farklı katılımcılardan seçilmiş, tekrarlayan, bulguları açıklamaya katkı sunan ve dikkat çekici olan görüşlerinin yansıtılmasına dikkat edilmiştir.

\subsection{Geçerlik ve Güvenirlik}

Farklı yöntemlerle (görüşme, gözlem, doküman analizi gibi) elde edilen verilerin birbirlerini teyit amacıyla kullanılması, araştırma sonuçlarının geçerliğini ve güvenirliğini artırmaktadır. Ayrıca bu konuda farklı bir strateji de ulaşılan sonuçların katılımcılar tarafından teyit edilmesini sağlamaktır (Yıldırım ve Şimşek, 2018). Bu araştırmada veri çeşitlemesi ve katılımcı teyidi stratejileri kullanılarak geçerliğin ve güvenirliğin yükseltilmesi ve sonuçların anlamlılığının zenginleştirilmesi amaçlanmıştır. Grup görüşmesi ve grup çalışması olduğu için bazı katılımcıların kendilerini yeterince ifade edemediği, görüşmelerde önceden ifade edilmiş görüşleri tekrarlamaktan kaçındığı, aynı şekilde günlüklerin düzenli yazılması konusunda bazı katılımciların gereken özeni göstermediği fark edilmiştir. Bu nedenle veri analiz raporu katılımcılarla sosyal ağ üzerinden daha önceden oluşturulmuş grupta yazılı olarak paylaşılarak analizlerin kendi algılarını ne ölçüde yansıttığına ilişkin fikirleri alınmış ve bu doğrultuda veriler yeniden düzenlenmiştir.

\subsection{Araştırmacının Rolü}

Araştırmacı, uygulamanın yapıldığı üniversitede çeşitli tarih derslerine girmektedir. Çalışma grubunu araştırma öncesinde farklı derslerde tanıma firsatına sahip olmuştur. Yakın tarih ve yerel tarih alanında çeşitli çalışmaları bulunan araştırmacı sözlü tarih yaklaşımını kendi çalışmalarında uzun zamandır kullanmaktadır. 2019-2020 öğretim yılında sosyal bilgiler öğretmenliği lisans programında Sosyal Bilgiler Öğretiminde Tarihsel Kanıt, Yerel ve Sözlü Tarih dersini açmış ve ilk kez vermiştir. Araştırmacı uygulamanın yürütülmesi, verilerin toplanması ve analizinde rol almıştır. Araştırmacının aynı zamanda dersin yürütücüsü olması katılımcılarda uygulama kapsamındaki her adımın değerlendirmeye etki edeceği yönünde bir kaygıya yol açma olasılığı bulunmaktadır. Katılımcılarda oluşabilecek bu kaygı, çalışmanın ciddiyetini artırma gibi olumlu bir etki de yaratabileceği gibi görüşlerin samimiyetle yansitılmasını olumsuz etkilemesi de mümkündür. Araştırmacı özellikle günlük yazma ve görüşmelerin değerlendirmeye hiçbir biçimde yansımayacağı, düşüncelerin samimi bir biçimde ifade edilmesinin araştırma sonuçlarının güvenirliği ve dersin şekillendirilmesi açısından önemli olduğu yönünde açıklamalar yaparak olası olumsuzlukları giderme çabası göstermiştir. Diğer 
yandan araştırmacı ve katılımcıların farklı dersler aracılığıyla birbirlerini iyi tanımalarının durumun daha iyi anlaşılmasına olumlu bir katkı sağladığı düşünülmektedir.

\section{BULGULAR}

\subsection{Sosyal Bilgiler Öğretmen Adaylarının Sözlü Tarih Uygulamasının Genel Kazanımlarına İlişskin Görüșleri}

$\mathrm{Bu}$ başlık altında ulaşılan kodlar kişisel, sosyal ve akademik gelişim temaları altında toplanarak Tablo 1'de verilmiştir.

Tablo 1. Öğretmen Adaylarının Sözlü Tarih Çalışmasının Genel Kazanımlarına İlişkin Görüşleri

\begin{tabular}{lc}
\hline & $(f)$ \\
\hline Kişisel Gelişim & 54 \\
\hline İletişim becerisi & 15 \\
Anlatıcıyla empati kurma & 13 \\
Farklı bakış açısı kazanma & 8 \\
Sabırlı olmayı örenme & 6 \\
Eleştirel düşünme & 5 \\
Sorumluluk duygusu & 3 \\
Özdenetim becerisi & 3 \\
Özgüvenin artması & 1 \\
\hline Akademik Gelişim & 48 \\
\hline Araştırma konusunu öğrenme & 18 \\
Sözlü tarih çalışmasını öğrenme & 12 \\
Mesleki gelişime katkı sağlaması & 9 \\
Bilimsel araştırma ve süreçleri hakkında bilgi sahibi olma & 6 \\
Klavye ile yazı yazma/ koordinasyon becerisi & 3 \\
\hline Sosyal Gelişim & 21 \\
\hline Yeni kişilerle tanışma & 8 \\
Çevreyi ve kampüsü tanıma ve farkındalık geliştirme & 8 \\
Üniversiteye karşı aidiyet duygusunun artması & 5 \\
\hline Toplam & 123 \\
\hline
\end{tabular}

Tablo 1 incelendiğinde kişisel gelişim teması altında ilk sırayı iletişim becerisi almaktadır. Bu konuda öğretmen adaylarının açıklamaları incelendiğinde iletişim becerisini çeşitli açılardan ele aldıkları görülmektedir. Ö12, "Proje insanlarla olan iletişimimizi kolaylaştırdı" şeklinde daha genel bir açıklama yaparken Ö16, "Ben iletişim kurma becerisi kazandı̆̆ımı düşünüyorum. Biraz daha cümlelerim değissti. Diksiyonum değişti... Mesela cümlelerimi ilk başta özne, yüklem gibi daha fazla kurguladım yani. Düzgün konuşma yetisini kazındığımı düşünüyor." açıklamasıyla konuşma konusunda eskisinden daha dikkatli davrandığını ifade etmiştir. İnsan ilişkilerinde çekingenliğini yendiğini ifade eden Ö5'in açıklaması ise şöyledir: "Çok çekingen bir insanım normalde. Sizin odanıza bile gelirken elli kere düşünen bir insanım. Hiç tanımadiğım insanların odasına girerken bunu biraz aşmayı başardım mesela. Bendeki etkilerinden birisi bu olmuştu”.

Öğretmen adaylarının çoğunun gerek görüşmelerde gerekse günlüklerinde yaptıkları açıklamalardan anlatıcıya karşı empati geliştirdiği anlaşılmıştır. Empati kavramı, Dökmen (2011) tarafından bir insanın kendini karşısındakinin yerine koyarak onun duygularını ve düşüncelerini doğru bir biçimde anlaması şeklinde tanımlamıştır. Öğretmen adaylarının kaynak kişileri dinlerken duygulandıkları, sık sık kendilerini anlatıcının yerine koydukları ve duygularını onlara hissettirdikleri anlaşılmaktadır. Bu konudaki bazı örnekler şöyledir: "Onlar anlattıkça benim gözümde canland o dönem. Kötü olaylarl hissetmiş gibi oldum. Bazen gözlerimiz doldu konuşurken" (Ö11), "Baya etkilendim açıkçası. Yaşamış gibi oldum” (Ö14). 
Anlatıcıya empati geliştiren bazı öğretmen adayları onları takdir ettiklerini ifade eden açıklamalar da yapmışlardır. Bu konuda bazı örnek açıklamalar şöyledir: "Bu kadar şeye rağmen nasıl okumuşlar diye düş̈̈ndüm. O insanlar şimdiki şartlarda okusalar nasıl başarılı olurlardı diye de düşündüm hani" (Ö1), "...Hani dediğim, okula gidememiş, zorluklar yaşamış biri hala kitap okuyorsa, yazlyorsa. Bizim şimdi ne sorunumuz var ki daha çok okumayalım dedim” (04). Öğretmen adaylarının yarısına yakını bu çalışmanın bakış açısında değişiklik yaratı̆̆ını belirtmiştir. "Bana farklı bir bakış açısı kazandırdı gerçekten” diyen Ö12, bu farklılaşmayı bazı konularda kendini sorgulama gereği hissettiği şeklinde açıklamıştır. Ö6'nın "Özellikle iki taraftan da dinlemek bana çok şey kattl. Çünkü ben de bazen tek bir bakış açısından baklyordum. İki tarafin da düşüncelerini dinlemek benim bakış açımı değiştirdi” ifadesi farklı bakış açılarını tanıma firsatı elde ettiğini, dolayısıyla kendi bakış açısında da değişiklik oluştuğunu göstermektedir. 2. grubun raporunda yer alan "Bu çalışma farklı açılardan hayata bakmamızı, empati kurarak o dönemin şartlarını, şimdiyle klyasladığımızda günümüzde Ege üniversiteli olmak ile 1970'lerde Ege üniversiteli olmanın avantaj ve dezavantajlarını görmemizi sağladı" ifadesinde de bu konuya değinildiği görülmektedir. Sabırlı olmayı öğrenme öğretmen adaylarının üçte biri tarafından ifade edilen bir kazanım olmuş ve bu kazanımı çoğunlukla sözlü tarih çalışmasında ve özellikle de görüşme kayıtlarının deşifre edilmesi konusunda yaşadıkları güçlüklerle ilişkilendirmişlerdir. Ö1 bu konuda çalışmanın etkisinden şöyle söz etmiştir: "Kişisel açılan faydası da sabrımın arttı̆̆ını düşünüyorum. Ben sabırlı değilim çok. Transkript yazarken özellikle kendimi zorlamayl, sabretmeyi ögrendim”. Aynı şekilde transkripsiyon süreci ile ilgili olarak Ö2, “...başka bir faydası da sabır. Sabır, ben aynı günde iki transkripti aynı anda yazmaya çalıştım” açıklamasını yapmıştır. Kişisel kazanımlar temasında ulaşılan farklı bir kazanım eleştirel düşünmedir. Ö17 şöyle bir çıkarımda bulunmuştur: "Fanatik olmamak da gerekiyormuş. Öyle düşündüm. ...Bazıları da ister istemez kendilerini olayların içinde bulmuş ama tabi ki katılmayanlar da olmuş". Sorumluluk duygusunun geliştiğinden söz eden bazı öğretmen adayları bu kazanımı özellikle grup çalışmasına bağlamışlar ve arkadaşlarına karşı kendilerini sorumlu hissettiklerini belirtmişlerdir. Bu konuda Ö2, "Grup bağlayıcı oluyor. Sorumluluk duygusu. Bir de insan kendine söz verdi mi bu işi yapacağım diye yapıyor. Bu bugün bitecek yani başka bir yolu yok diyorsun”" şeklinde açılama yaparken Ö18, "Ben bireysel bir ödev olsa bu kadar uğraşmazdım” demiştir. Özdenetim konusu özellikle 2. grubun raporunda vurgulanmıştır. Ö11 ise bu çalışma sayesinde özgüvenin geliştiğini belirtmiştir.

Öğretmen adayları sözlü tarih çalışmasının akademik gelişim temasıyla ilgili kazanımlarını da dile getirmişlerdir. Bu konuda öğretmen adaylarının tamamı proje konusu olan 1970'li yıllarda Ege Üniversitesi'nde öğrencilik yaşamını çok iyi öğrendiğini ifade etmiş ve proje sayesinde dönem hakkında bilgi sahibi olduklarını belirtmişlerdir. Öğretmen adaylarının büyük bir çoğunluğu sözlü tarihi öğrendiğini ifade etmiştir. Ö9'un bu konudaki açıklaması şöyledir: "Şöyle akademik anlamda ileride ögrretmen olduğumda açıkçası böyle bir proje yürüttü̈̆̈̈mde öğrencilerime nasıl destek olmam gerektiğini ögrendim... Sözlü tarihi öğrendim. Öğrencilerimle yapabilirim”. Sözlü tarihin öğrenildiği konusu grup proje raporlarında da vurgulanan bir konu olmuştur. Bu konuda proje raporlarından bazı örnekler şöyledir: "Bu proje bize sözlü tarih çalı̧̧masının yürütülme şekli ve bilgileri sentezleyip bir bütün haline getirme açısından oldukça yararlı oldu. O zaman yaşayan birincil kaynaklardan bilgi edinildi. Sözlü kaynak çalışmasının nasıl yapılacă̆ı ögrenildi" (3. Grup). "Bu projenin bize kazandırdı̆̆ en önemli şey; bir sözlü tarih çalışmasının nasıl yapılması gerektiğini, uyulması gereken prosedürleri, uygulama aşamalarının nasıl yapılacağına dair bilgi sahibi olmamızı sağlamasıdır" (5. grup). Öğretmen adaylarının yarısı sözlü tarih çalışmasının mesleki gelişim açısından kendilerine katkı sağladığını ifade etmiştir. Bu katkıları öğretmenlik becerilerinin geliştiği, sosyal bilgiler alan becerilerinin kazandırılması konusundaki faydalarını anlamalarını sağladığ1 ve öğrencilerine çok iyi rehberlik yapabileceklerini öğrendikleri şeklinde açıklamışlardır. Bazı öğretmen adayları (Ö3, Ö5, Ö9, Ö12) sözlü tarih çalışması sürecinde 
öğrencileriyle nasıl çalışmalar yapabileceklerini hayal ettiklerini belirtmişlerdir. Bu konuda bazı örnekler aşağıda verilmiştir:

...Ben ileride öğretmen olduğumda öğrencilerimle buna benzer nasıl bir çalışma yaparım diye hep düşündüm açıkçası ve onlara gerçekten iyi bir danışman olacağımı düşünüyorum. Çünkü çok fazla şey öğrendim. Benim o günden beri hep kafamda, ben acaba öğrencilerimle nasıl bir proje geliştirebilirim diye... Arkadaşlarımla görüşme yapmalarını isterdim... Bu ilk günden beri aklıma takıldı. İleride inşallah öğretmen olduğumda böyle bir çalışma yapmayı düşünüyorum. Kesin yapacağım yani... (Ö9).

... dönem içinde öğrencilere bazı projeler veriliyor ya ben onu kullanırdım. Çünkü ben öğrenciliğimden hatırlıyorum bu tür ödevler genelde şöyle olurdu: Bir konu hakkında internette araştırma yap, onu kâğıda yaz ve getir. Evet, okey ama öğrencilerin insanlarla iletişim haline geçmesinin o yaşlarda başlaması daha mantıklı olurdu. Ben büyük ihtimalle öğrencilerimin böyle bir çalışma içinde yer almalarını sağlamak isterdim diye düşünüyorum. (Ö12).

Sözlü tarih çalışması yürütmenin öğretmen adaylarında bilimsel araştırma yapma ya da bilimsel araştırma ile ilişkili araştırma yapma, sentez yapma, rapor hazırlama, referans gösterme, kaynakça hazırlama gibi bazı süreçlerin öğrenilmesine katkı sağladığı anlaşılmaktadır. Bu konuda öğretmen adaylarının açıklamalarından bazı örnekler şöyledir: "Akademik anlamda işte rapor nasıl yazılır? Araştırma nasıl yapılır? Bunlar hakkında genel fikir sahibi olduk. Tecrübemiz, deneyimimiz oldu" (Ö3), "Mesela geçen sene Türk dili dersinde kaynak göstermeyi ve kaynakça yazmayı ögrendik ama uygulamadık. Bu proje bizim için çok iyi oldu. Çünkü ben artık nasıl kaynak göstereceğimi ve nasıl kaynakça yazacağımı biliyorum. Hiçbir yere bakmadan yapabilirim" (Ö6). Akademik kazanımlar kategorisinde 3 öğretmen adayının da klavye ile yazı yazma ve koordinasyon becerisine vurgu yaptıkları görülmüş̧ür. "... transkripti yazarken direk koordinasyon bir şekilde yazıyoruz. Onu aşırı bir şekilde gelişstiriyor. Duyduğun anda yazlya geçiriyorsun... duyduğun anda yazıya geçirme konusu biraz katipliğe giriyor. Onu aşırı derecede geliştiriyor. Şu an mesela kâtiplik sinavına girsem kesin kazanırım" (Ö2). Ayn1 şekilde Ö14 "Klavye ile yazı yazma becerimin geliştiğini düşünüyorum" açıklamasını yapmışırı.

Sözlü tarih çalışmasının sosyal açıdan da çeşitli kazanımlar sağladığı anlaşılmaktadır. Özellikle 8 öğretmen adayı yeni kişiler tanıdıklarını, sosyal çevrelerinin genişlediğini açıklamıştır. Ö1'in bu konudaki açıklaması şöyledir: “... çok iyi hocalarla tanıştık. Bazı etkinliklere davet ettiler bizi. Yardıma ihtiyacınız olursa gelin dediler. O yönden iyi oldu. Çevremiz genişledi”. 1. grubun üyeleri ise görüşme yaptıkları kaynak kişilerden biriyle sohbet etmek amacıyla birkaç kez daha görüştüklerini ve sınavların bittiği gün birlikte yemek yiyeceklerini belirtmişlerdir. Yine öğretmen adaylarının 8'i bu proje sayesinde kampüsü ve çevrelerini daha iyi tanıma fırsatı bulduklarını ifade etmişlerdir. Buna ilişkin örnekler şöyledir: “...Sonra fakülte fakülte gezince, mesela Tip'a girdik. Tip’tan, Çocuk Hastanesi, Tip’ın bir bloğundan çıkınca Hemşirelik Fakültesi'nin önünde bulduk kendimizi. Yani her yeri gezdik" (Ö8), "Asıl Ziraat Fakültesi çok güzelmiş onu öğrendik" (Ö9). Öğretmen adaylarının özellikle görüşme yapacak kaynak kişi bulmak amacıyla kampüs içinde yoğun bir arayışa girmelerinin ve 1970'li yıllarda mevcut olan fakülteleri araştırmalarının bu duruma katkısı olduğu anlaşılmaktadır. Diğer yandan Ö11'in "Sadece şöyle oldu. Yolda gidiyorum mesela aa bunlar o zamanda yoktu diye düşünüyorum" açıklaması ise çevresine karşı farkındalığının arttığını göstermektedir. Sosyal açıdan 5 öğretmen adayı üniversiteye karşı aidiyet duygusunun geliştiği konusuna vurgu yapmıştır. Ö1'in bu konudaki açıklaması şöyledir: "Hani köklü diyorlardl. Geldiğimde çok ciddiye almamıştım ama araştırmada gerçekten de köklü bir üniversite ve başarll bir üniversite olduğunu daha iyi anladım... Ben daha çok benimsedim galiba. Bana böyle tuhaf bir katkısı oldu. Öğrendikçe tarihini daha çok benimsedim" diğer yandan 4. grubun raporunda da bu kazanımla ilişkili “...kuruma karşı daha çok pekişen bir aidiyet duygusundan bahsedebiliriz. Sıkça karşılaştırma yapar olduk, çevremize karşı duyarlılığımız arttı” ifadesine rastlanmaktadır. 


\subsection{Sosyal Bilgiler Öğretmen Adaylarının Sözlü Tarih Uygulamasının Tarihsel Öğrenme ve Tarihsel Düşünmeye Etkisine İlişkin Görüşleri}

Sosyal bilgiler öğretimi programında yer alan zaman ve kronolojiyi algılama, değişim ve sürekliliği algılama, tarihsel empati, kalıp yarg1 ve önyargıları fark etme ve kanıt kullanma tarihsel düşünme becerileriyle ilişkilidir. Bu çalışmada öğretmen adayları dönemi birincil sözlü kaynaklardan araştırmış, sundukları proje raporlarında farklı kaynakları karşılaştırarak sentez yapmış, dönemi analiz etmiş ve günümüzle karşılaştırmışlardır. Öğretmen adaylarının sözlü tarih projesinin tarihsel öğrenme ve düşünmeye katkısına ilişkin görüşleri Tablo 2'de verilmiştir.

Tablo 2. Öğretmen Adaylarının Sözlü Tarih Çalışmasının Tarihsel Öğrenme ve Düşünmeye Etkisine İlişsin Görüşleri

\begin{tabular}{lc}
\hline & $(f)$ \\
\hline Konunun çok iyi öğrenilmesi & 18 \\
Tarihsel empati geliştirme & 18 \\
Değişim ve sürekliliği tanımlama & 17 \\
Aynı konu hakkında farklı bakış açılarını tanıma (çoklu bakış) & 13 \\
Gelecek hakkında düşünme & 8 \\
Ders kitapları ve yazılı materyallerde bulunamayacak bilgiler edinme & 5 \\
Daha önceden öğrenilen bilgilerin somutlaşması ve kalıcılığının artması & 5 \\
Konuya daha geniş bir yelpazeden bakabilme & 4 \\
Günümüzle ilgili kendi farkındalığını sorgulama & 4 \\
Konuya ilginin artması ve daha fazla araştırma isteğinin oluşması & 2 \\
\hline Toplam & 94 \\
\hline
\end{tabular}

Tablo 2 incelendiğinde öğretmen adaylarının tamamı araştırdıkları konuyu ve dönemi çok iyi öğrendiklerini ifade etmişlerdir. Bu konuda bazı açıklamalar şöyledir: "Sonuçta sosyal bilgiler öğretmeni olacağız. 70’ler dönemi inkılap tarihi kapsamında bizim gördüğümüz konular. Bu proje dönemi daha iyi ögrenmemizi sağladı bence her yönden" (Ö1). "Aslında ben günümüz tarihini hiç bilmiyormuşuz gibi hissettim. Tamam, oldu darbe falan diyoruz ama. $O$ kadar yüzeysel ki bunlar... Röportajlar sayesinde bunlar yaşayan insanların ne yaşadıklarını çok iyi kavramış olduk" (Ö15). Yine proje konusuyla bağlantılı olarak sözlü tarih yöntemi sayesinde ders kitapları ve yazılı materyallerde bulamayacakları bilgilerin edinildiği; dönem hakkında önceden öğrenilmiş bilgilerin somutlaştığı ve kalıcılığının arttığı; konunun faklı açılardan öğrenildiği şeklinde kazanımlar ifade edilmiştir. Bu kazanımlara ilişkin öğretmen adaylarının açıklamalarından seçilmiş bazı örnekler aşağıdadır:

“...Tarih dersini ... Hoca anlatıyordu ama ne kadar anlatsa da uçup gidiyordu. Karşı taraftan duyunca ve gerçekten o anı kafada canlandırınca bilgi daha çok oturdu. Birinci ağızdan duyunca daha kalıcı oldu bence.” (Ö8)

“...akademik anlamda ben de tarihi bilgilerinin daha çok yerleştiğini, anlatılan anılarla daha netleştiğini gördüm.” (Ö12)

"Normalde sadece araştırma ile kalsaydı böyle birebir görüşme imkanımız olmasaydı belki de bu kadar iz bırakmazdı bu kadar yerleşmezdi." (Ö14).

"Ben ders kitaplarını, ortaokul olsun, lise olsun fazla beğenmiyorum. Çoğu kişilerde bunları okumuyor. Hep bir genel kalıp var. Bu kalıbın etrafında her şey dönüyor. Yaşamış kişilerden dinleyince çok daha farklı.” (Ö18),

“Türk siyasetinde saklı kalan bazı şeyleri öğrendik...”(Ö17)

“Çalışma sayesinde daha geniş yelpazeden bakabildik yetmişlere.” (Ö2)

Öğretmen adaylarından bazıları sözlü tarih çalışmasının incelenen döneme ilişkin merak ve araştırma isteği uyandırdığını ifade etmiştir. Ö10 bu konudaki düşüncesini "Gerçekten de görüş̧me yaptıktan sonra öyle oldu. Mesela Tariş Olayları, hani okulda yaşanan siyasi 
çatışmalar sonucunda ölen insanlar, insanların kaybettikleri arkadaşları beni çok etkiledi. Yani araștırmaya sevk etti beni. Projenin en sevdiğim yanı buydu" șeklinde ifade ederken, Ö7 “...Daha sonra araştırma konusunda faydası oldu. Sürekli bir araştırma içinde olmam gerekiyordu. Konuşulan şeyleri araştırma gereği hissettim” açıklamasını yapmıştır.

Sözlü tarih çalışmasının öğretmen adaylarının tamamında tarihsel empati becerisini geliştirdiği görülmüştür. Tarihsel empati dönemin koşullarına uygun olarak geçmişteki insanların düşünce, amaç ve duygularını anlama becerisidir. Proje konusunun da uygun olması nedeniyle bütün öğretmen adayları dönemi çeşitli açılardan analiz edebilmiş ve kendi yaşamları ile incelenen dönemin yaşantısı arasında bağ kurmaya çalışmışlardır. Ayrıca dönemi deneyimlemiş kişilerden dinlemenin verdiği gerçeklik ve duygu sayesinde sıklıkla dönemin koşullarını hissedebildiklerini ifade etmişlerdir. Buna ilişkin bazı örnekler şöyledir:

"Aslında iki taraf da ülkenin kurtuluşunu istiyor. Olumlu şeyler istiyor fakat insanlar
kutuplaşıyor ve bu kutuplaşmanın getirdiği talihsizlikten ötürü eğitim hakları sekteye
uğruyor bence ve iki tarafın da kendince haklı olduğunu düşünüyorum" (Ö17).

“...yurtlara askerlerin, jandarmaların baskı yaptığını anlattıklarında şu an ben de o yurtta kalıyorum ve gözümde o canlanıyor benim. Dolaplarımı, kitaplarımı karıştırdıklarını düşünüyorum ve böyle olsa nasıl hissederdim diyorum” (Ö12).

“...Ziraat Fakültesi’nde Sezen Aksu sabahları şarkı söylüyormuş çay içerken. Biz de geçen gün yemekten sonra orda çay içiyorduk bir an böyle gözümüzde canlandı. Sezen Aksu burada şarkı söylüyormuş gibi...." (Ö6).

"Bu projede yer almak bana o dönemi hissetmemi sağladı. Hatta bazı görüşmelerde duygulandığım oldu" (Ö11).

"O kişiler ne yaşamış o anda, sınav anında dersliklerin basılması, hocaların gitmesi ya da o çatışma ortamında kalmak, bir yerlere saklanmak gerçekten çok kötü” (Ö10),

"Genel olarak baktığımızda durum bu şekilde hocalarımız o günleri anlatırken beraber duygulansak da ben şimdiki zamanda kalmayı tercih ederdim” (Ö13).

Öğretmen adaylarının gerçekleştirdikleri sözlü tarih çalışması sonucunda o dönemin üniversite yaşantısı ile günümüzün üniversite yaşantısı arasında karşılaştırma yaparak olumlu ve olumsuz açıdan gördükleri değişimi ve değişmeyen yönleri belirleyerek proje raporunda açıklamaları istenmiş ve bir grup dışında bütün gruplar raporlarında dönem karşılaştırmasına yer vermiştir. Ayrıca odak grup görüşmelerinde bu konu tekrar sorulmuştur. Öğretmen adaylarının büyük bir çoğunluğu bu konuda yapmış oldukları çıkarımlarla ilgili görüş bildirmiştir. Ö16'nın buna ilişskin açıklaması şöyledir: "Beceri olarak da sosyal bilgilerde değişim ve sürekliliği algılama becerisi var ya. Karşılaştırma yapabildim o dönemle bu dönem arasında". Dönemlerin karşılaştırılmasında öğretmen adayları, üniversitenin yemekhane sayısı, kültürel açıdan çeşitliliği ve öğrencilerin ekonomik sorunlar yaşaması konusunda değişim olmadığını ifade etmişlerdir. Bazı öğretmen adayları siyasetin hem o dönemde hem de bu dönemde öğrencilik yaşamını etkilediğini belirtirken büyük bir çoğunluk o dönemde siyasetin daha çok belirleyici olduğunu söylemiştir. Siyasi hoşgörünün artması, üniversitenin kampüs olanaklarının ve sosyal etkinliklerinin artması, ulaşım olanakları ve teknolojinin gelişmesi özellikle de eğitim teknolojisindeki gelişme pek çok öğretmen adayı tarafından olumlu değişim olarak ifade edilmiştir. Olumlu değişime yönelik öğretmen adaylarının açıklamalarından bazı örnekler şöyledir: "Hoşgörü daha çok artmış gibi. Yani siyasi olarak bahsediyorum. O dönemde insanlar arası hoşgörü daha çok ama sağ sol bazında bir hoşgörüsüzlük var" (Ö4), "Bence kampüs yaşantısı olarak şimdi o zamana göre baya gelişmiş Ege Üniversitesi" (Ö9), "Teknoloji çağındayız. Telefonlardan hiç ayrılmıyoruz neredeyse. Onlar o zaman PTT'ye gidip bir kişiyle görüşebilmek için saatlerce bekliyorlarmış" (Ö6). Öğretmen adayları iş bulma, gelecek kaygısı yaşama, arkadaşlık ilişkileri, üniversiteli algısı, öğrencilerin çalışma azmi ve kampüsteki yeşilliğin azalması konusunda olumsuz değişim olduğunu ifade etmişlerdir. Olumsuz değişime Ö8'in şu açıklamasını örnek vermek mümkündür: “...Okulu bitirdikten sonra hemen işe 
başlayabiliyorlarmış. Ben diyorum ki keşke bu zamanda da olsaydı". Özellikle arkadaşlık ilișkilerindeki olumsuz değișim konusu her iki odak grup görüșmesinde de gündeme gelmiș ve öğretmen adaylarının kendi sınıflarındaki arkadaşlık ilişkilerini sorgulamasına yönelik uzun bir tartışmanın yaşanmasına neden olmuştur. Bu tartışmalarda özellikle gruplaşmaların artması, çıkar amaçlı ilişkiler kurulması, sanal ortamdaki samimiyetin gerçek yaşama yansıtılmaması gibi yakınmalar ön plana çıkmıştır. Bu konudaki bazı örnek açıklamalar şöyledir: "Evet, onu ben de çok yaşlyorum. Bana mesela Whatsapp'ta canım diyor sabah beni gördüğ̈̈nde yüzüme bile bakmiyor" (Ö9), "Eskiden iki grup vardı să̆ ve sol diye. Şimdi bizim sinıfa bakarsak on grup var ...normal arkadaş grupları, kimse kimseyle ilgilenmiyor" (Ö3). Kadın erkek ilişkileri ve aşk konusundaki değişim bazı öğretmen adayları tarafindan olumlu bulunurken bazıları tarafindan olumsuz olarak değerlendirilmiştir. Ö1'in bu konudaki açıklaması şöyledir: "Kadın erkek ilişsilerinden de bahsettiler. Ya evlenmek zorundaymışsınız. Ya da böyle arkadaş gibi olabilirsiniz... Ortası yokmuş". Ö3 ise kadın erkek ilişkilerindeki duygusal boyutun azaldığından yakınarak "Konuştuğumuz insan da diyordu. 'bir dokunuşa şiirler yazılmalı' diye. Bu dönemde şair yok. Evlenen de çok yok".

Öğretmen adaylarının çoğu geçmiş yaşantılarla ilgili aynı konu hakkında farklı bakış açılarını keşfettiklerini ifade etmişlerdir. Örneğin Ö17'nin bu konuya ilişkin açıklaması şöyledir. "Farklı siyasi bakış açılarını ögrendim. Siyasete zaten oldukça ilgim vardı. Seçtiğimiz dört kişi de farklı siyasi bakış açılarına sahipti. Hepsini dinleyip hepsiyle de empati kurabilmek farklı bir şeydi onu fazlasıyla hissettim". Öğretmen adaylarının yarısına yakını bu projenin gelecek hakkında düşünmelerine yol açtığını ifade etmiştir. Bu konuda Ö6'nın açıklaması şöyledir:

Bir de şöyle düşündüm. Onlar da o zamanlar bizim yaşımızdaymış. Şimdi aradan kaç sene geçmiş. Fikirleri nasıl değişmiş. Acaba diyorum ki şimdi bizim de heyecanlandığımız çok tepki gösterdiğimiz şeyler ileride bize çok basit gelebilir mi? Acaba gereksiz şeylere mi tepki gösteriyor ya da heyecanlanıyoruz onların o zamanki hali gibi? Ayrıca böyle gelecekle de bir bağlantı kurmamamı sağladı.

Bazı öğretmen adaylarının birbirleriyle sözlü tarih görüşmeleri yaptıkları anlaşılmaktadır. Buna ilişkin Ö7'nin günlüğündeki açıklama şöyledir: “Raporumuzu yazmayı bitirdikten sonra diğer gruptaki arkadaşlarımızla birlikte birbirimizle röportaj yaptık. Kendimizi 10 sene sonrasına götürdük”. Bu örnekler sözlü tarih çalışmasının öğretmen adaylarını gerek kendi gelecekleri gerekse genel olarak gelecek yaşamın nasıl olacağı konusunda düşünmeye sevk ettiğini göstermektedir. 4 öğretmen adayı ise bu çalışma sayesinde günümüz gelişmelerine ilişkin kendi farkındalığını sorguladığını belirtmiştir. Bu konuda Ö12'nin açıklması şöyledir:

...Hatta şöyle düşündüm. Bana böyle bir araştırma için gelseler neler anlatırım şu an... Şöyle dedim. Mesela ben bugün siyasi olaylara dair neler biliyorum? Kampüs hakkında neler biliyorum? Onlara sorduğum soruları kendime de sordum. Bir nevi röportaj gibi, dedim hani neleri biliyorum? Nelerle ilgiliyim? Bana öğrenciler gelse onlara yeterli bilgileri verebilir miyim? ...diye düşündüm.

\section{TARTIŞMA, SONUÇ VE ÖNERILER}

Bu araştırmada Sosyal Bilgiler Öğretiminde Tarihsel Kanıt, Yerel ve Sözlü Tarih dersi kapsamında gerçekleştirilen örnek bir uygulama ile sosyal bilgiler öğretmen adaylarının sözlü tarih çalışmasından edindikleri genel kazanımlar ile çalışmanın tarihsel öğrenme ve düşünmeye katkılarına ilişkin görüşleri incelenmiştir. Öğretmen adaylarının sözlü tarih çalışmasından edindikleri genel kazanımlar kodlanarak akademik, kişisel ve sosyal gelişim temaları altında toplanmıştır. Kişisel gelişim kazanımları temasında çoğunlukla iletişim becerisine vurgu yapılmış ve bu kapsamda, insanlarla daha kolay iletişime geçebilme, daha özenli cümleler kurma, insan ilişkilerinde çekingenliği aşma gibi konularda fayda sağladığ 1 belirtilmiştir. Bu bulgular çeşitli öğrenim kademelerindeki öğrencilerle yapılan araştırmaların 
(Çelik, 2018; Dere ve Dinç, 2018; Dere, 2018) sonuçlarıyla uyumludur. Bu çalışmada öğretmen adaylarının büyük bir çoğunluğu görüşme yaptığ 1 kişiyle empati kurabilmiştir. $\mathrm{Bu}$ sonuç Sarı ve Türküresin (2018), Aktın ve Sağlam-Tekir (2018) ile Çelik'in (2018) çalışmalarını desteklemektedir. Diğer yandan Welton ve Mallan, (1988), Sarı (2007) ve Sarı ve Türküresin'in (2018) araştırmalarındaki sözlü tarihin öğrencilere kendinden önceki kuşakları daha iyi anlama ve takdir etme becerisi kazandırdığı yönündeki saptamaları bu çalışmada da ulaşılan sonuçlardan biridir. Öğretmen adaylarının yarısına yakını bu çalışma sayesinde farklı bakış açısı kazandıkları ya da bu çalışmanın bakış açılarında değişikliğe neden olduğunu ifade etmişlerdir. Bu sonuç Dere'nin (2018) öğretmen adaylarının yeni bakış açıları kazandığı bulgusunu desteklemektedir. Çalışmada öğretmen adaylarının görüşleri doğrultusunda ön plana çıkan diğer bireysel kazanımlar eleştirel düşünme, sabırlı olmayı öğrenme, özdenetim becerisi ve sorumluluk duygusudur. Bu kazanımlar, Dutt-Donera ve diğerleri (2016) ile Dere'nin (2019), sözlü tarihin sorgulama, eleştirel düşünme becerilerini geliştirdiği görüşüyle örtüşmektedir. Sözlü tarih çalışmasının sorumluluk duygusunu geliştirdiği Dere ve Dinç (2018) ile Sarı ve Türküresin'in (2018) çalışmalarında ulaşılan bir sonuçtur.

Öğretmen adaylarının bir bölümü bu uygulama sayesinde sözlü tarih çalışması yapmayı öğrendiklerini ifade ederken mesleki gelişime katkı sağladığı yönünde görüş bildiren öğretmen adayları da bulunmaktadır. Bu çerçevede bazı öğretmen adayları öğretmen olduklarında böyle bir çalışma yapmayı düşündüklerini ifade etmişlerdir. Hatta nasıll bir çalışma yapabileceklerine ilişkin düşünceler geliştirdikleri de anlaşılmaktadır. Öğrencilerin ve öğretmen adaylarının iyi bir rehberlik yapıldığında örnek uygulamalarla sözlü tarih çalışmalarını nasıl yürüteceklerini öğrenebildikleri bazı araştırmalarda (Doğan, 2015; Çelik, 2018) ortaya konmuştur. Ka1lımcıların sözlü tarih deneyiminden ileriki yaşamlarında yararlanma düşüncesi ise Lattimer ve Kelly (2013), Demircioğlu (2016) ile Aktın ve Sağlam-Tekir'in (2018) araştırma sonuçlarını desteklemektedir. Araştırmada öğretmen adaylarının üçte biri sözlü tarih çalışması ile bilimsel bir çalışmanın nasıl yürütüleceği konusunda önemli kazanımlar elde ettiğini birkaç öğretmen adayı ise görüşmelerin deşifre edilmesi sayesinde klavye kullanma ve koordinasyon becerilerinin arttığını belirtmiştir. Sözlü tarihin sosyal gelişim açısından kazanımları kategorisinde yeni kişilerle tanışma; çevreyi ve kampüsü tanıma ve farkındalık geliştirme ve üniversiteye karşı aidiyet duygusunun artması araştırmada ortaya çıkan önemli bulgulardır. Sözlü tarih çalışmasının araştırma becerilerini geliştireceği Demircioğlu'nun (2007) çalışmasında belirtilen bir durumdur. Diğer yandan sözlü tarihin bilimsel araştırmanın aşamalarını deneyimleme ve farklı insanlarla tanışma kazanımları Dere'nin (2018) araştırma sonuçlarıyla uyumluluk göstermektedir.

Araştırmanın ikinci sorusu öğretmen adaylarının gerçekleştirdikleri sözlü tarih çalışmasının tarihsel öğrenme ve tarihsel düşünmeye katkısına ilişkin görüşlerini incelemeye yöneliktir. Öğretmen adaylarının görüşleri doğrultusunda sözlü tarih yönteminin tarih konularını öğrenmede güçlü bir etkiye sahip olduğu bu araştırmanın ortaya koyduğu bir sonuçtur. Ayrıca sözlü tarih çalışmasıyla ders kitapları ve yazılı materyallerde bulunamayacak bilgileri edinmenin mümkün olduğu; öğrenilen bilgilerin somutlaşmasına ve kalıcılığının artmasına katkı sunduğu; konuya geniş bir yelpazeden bakmayı sağladığı; konuya ilişkin merak ve araştırma isteğini artırdığı şeklinde görüşler ortaya çıkmıştır. Bu sonuçlar ilişkili diğer araştırma sonuçlarıyla karşılaştırıldığında Lattimer ve Kelly'in (2013) sözlü tarih çalışmasının ders kitaplarındaki eksiklerin fark edilmesini ve içeriğin daha iyi anlaşılması sağladığ 1 , Dutt-Donera vd. (2016) ile Çelik'in (2018) katılımcıların tarih bilgisinin artmasına katkı sağlayarak, onları daha çok araştırmaya yönelttiği sonucuyla uyumludur. Aktın ve Sağlam-Tekir'in (2018) sosyo-kültürel tarih konularına dair ayrıntılı bilgiler edinmeyi sağlayarak tarihte eksik kalan yanları tamamladığı sonucuyla benzerlik göstermektedir. Diğer yandan bu araştırmanın bulguları, Metin ve Öz'ün (2019) sözlü tarih çalışmalarının öğrencilerin ders kitabındaki bilgileri sorgulamasını, olaylar hakkında yeni sorular sormasını, ders kitabında yer verilmeyen tarihi şahsiyetlerin bakış açılarını araştırmasını ve ders kitabının 
tamamıyla veya kısmen göz ardı ettiği bir konuyu derinlemesine inceleyebilmesini sağladığı yöndeki görüşünü de desteklemektedir.

$\mathrm{Bu}$ araştırmada proje konusunun yerel tarih ve özellikle de öğretmen adaylarının öğrenim gördükleri kurumun geçmişiyle ilişkili olması bazı tarihsel düşünme becerilerini edinme ve bu konuda farkındalık sağlamaya yönelik önemli sonuçlar ortaya koymuştur. Katılımcıların tamamı tarihsel empati, tamamına yakını ise değişim ve sürekliliği tanımlama becerisi göstermiş ve sözlü tarih çalışmasının bu becerilerin gelişimine katkısını fark etmiştir. Geçmiş ve günümüz karşılaştırmasını proje raporlarında ifade eden öğretmen adayları, odak grup görüşmelerinde bu konuya geniş yer vermiş ve özellikle geçmişteki öğrencilerin arkadaşlık ilişkilerinden yola çıkarak kendi arkadaşlık ilişsilerinde gördükleri sorunlarla ilgili uzun uzun tartışmışlardır. Öğretmen adayları bu çalışmada aynı konu hakkında birden fazla kişiyle görüşme yapmış ve rapor hazırlarken farklı bilgileri sentezleme firsatına sahip olmuşlardır. Dolayısıyla bu durum öğretmen adaylarının çoğunun farklı bakış açılarını tanıma firsatı elde etmelerine katkı sağlamıştır. Sözlü tarihin geçmişteki olaylara ilişkin farklı bakış açılarını tanımaya katkısına ilişkin bulgular, Dutt-Donera vd. (2016), Demircioğlu (2016), Çelik (2018), Dere (2018) ve Açıkalın'ın (2018) çalışmalarıyla uyumludur.

Araştırma, sözlü tarih çalışmasının katılımcıların hem günümüzle ilgili farkındalıklarını sorgulamasına hem de gelecek hakkında düşünmelerine etkisi olduğunu göstermiştir. Özellikle bazı öğretmen adaylarının görüşmelerde kaynak kişilere yönettikleri sorular çerçevesinde günümüz veya geleceği düşünerek kendi aralarında sözlü tarih görüşmeleri gerçekleştirdiği görülmüştür. Bu bulgular, Neyzi'nin (2019) araştırmasında ortaya koyduğu sözlü tarih yapmanın öğrencilerin kendi yaşamlarına olan ilgilerini $\operatorname{artırdığ~} 1$ yönündeki bulgusunu desteklemektedir. Sözlü tarih çalışmalarının değişim ve sürekliliği algılamaya katkısı özellikle küçük yaş gruplarıyla gerçekleştirilen sözlü tarih çalışmalarında (Kabapınar ve İncegül 2016; Dere ve Emeksever, 2018) ulaşılan sonuçlardandır. Genel olarak ikinci araştırma sorusu doğrultunda ulaşılan tarihsel düşünme becerileri kazandırdığı, derin tarihsel anlayış geliştirdiği, tarihsel içerik bilgisini artırdığı, tarihçi gibi düşünme ve çalışma becerisi kazandırdığı yönündeki bulgular diğer araştırma sonuçlarıyla uyumludur (Aktın ve SağlamTekir, 2018; Busby, 2011; Dere, 2019; Doğan, 2015; Dutt-Donera vd., 2016) Bu araştırma Thompson'un (1999) görüşmelerdeki keşif duygusunun sağlam bir tarihsel boyut kazandırdığ 1 ve geçmişle ilgili farkındalık duygusunun yalnızca bilgi düzeyinde kalmayarak kişisel olarak hissedildiği görüşünü de desteklemektedir.

Sonuç olarak sosyal bilgiler öğretmen adaylarının ders kapsamında yürüttükleri sözlü tarih projesi, kişisel, akademik ve sosyal açıdan önemli kazanımlar elde etmelerini sağlamıştır. İletişim, empati, eleştirel düşünme ve farklı bakış açısı kazanma gibi önemli kişisel kazanımlar sağlamanın yanı sıra sözlü tarih çalışmasının temel ilkelerini öğrenirken aynı zamanda bilimsel bir araştırmanın nasıl yürütüleceğine ilişkin fikir sahibi olmuşlardır. Öğretmen adayları sözlü tarih çalışmasının tarihsel konuların öğretiminde etkili, çok yönlü ve kalıcı öğrenmeyi artıran güçlü bir araç olduğunu keşfetmişlerdir. $\mathrm{Bu}$ araştırma lisans eğitiminde sözlü tarih çalışması deneyimlemenin, öğretmen adaylarının bu yöntemi mesleki yaşamlarında kullanma konusunda teşvik edici olabileceğine dair önemli bulgular sağlamıştır. Sözlü tarih araştırmasında yerel tarih (öğrencilerin içinde bulunduğu topluluk) konularının seçilmesinin tarihsel empati, değişim ve sürekliliği tanımlama, yakın çevreye yönelik farkındalık geliştirme, yer aldığı topluluğa ilişkin aidiyet duygusunu geliştirme ve özellikle de günümüzü sorgulayarak gelecek hakkında düşünmeye sevk etme konusunda önemli katkılar sağladığını göstermiştir. Yerel bazda yapılan araştırma tarihsel bir döneme ve genel olaylara ilgiyi de artırmıştır. Araştırma sonuçlarından yola çıkarak okullarda öğretmenlerin sözlü tarih yöntemini daha fazla kullanmasını teşvik etmek amacıyla sınıf öğretmeni, sosyal bilgiler öğretmeni ve tarih öğretmeni adaylarının lisans eğitiminde sözlü tarih çalışmasını deneyimlemesine fırsat sağlanmas1 gerektiği önerisini getirmek mümkündür. 2018 Sosyal Bilgiler Öğretimi Lisans programında yer alan Sosyal Bilgiler Öğretiminde Tarihsel Kanıt, Yerel ve Sözlü Tarih 
seçmeli dersi, bu tür uygulamaların yapılmasına olanak sağladığından tarih öğretmenliği, sınıf öğretmenliği gibi anabilim dallarını da kapsayacak şekilde daha fazla kurumda açılması yararlı olacaktır. Diğer yandan üniversiteler ve milli eğitim müdürlükleri arasında işbirliği yapılarak hizmetiçi eğitim programları aracılığıyla sözlü tarih yöntemini öğretmenlerin de deneyimlemesine firsat verilmesinin önemli olduğu anlaşılmaktadır.

\section{KAYNAKÇA}

Açıkalın, M. (2018). Araştırmaya dayalı sosyal bilgiler öğretimi. (2. Baskı), İstanbul: Yeni İnsan Yayınevi.

Akbaba, B. ve Kılcan, B. (2014). Sosyal bilgiler öğretmen adaylarının sözlü tarih çalışmalarına yönelik tutumları. Illköğretim Online, 13(3), 746-758.

Aktın, K. ve Sağlam-Tekir H. (2018). Sosyal bilgiler öğretmen adaylarının sözlü tarih yapmakla ilgili deneyimleri. International Online Journal of Educational Sciences, 10 (2), 295-310. DOI: https://doi.org/10.15345/iojes.2018.02.020

Beldağ, A. ve Balcı, M. (2017). Sosyal bilgiler öğretiminde sözlü tarih yönteminin kullanımı: Nitel bir çalışma. Uluslararası Türk Eğitim Bilimleri Dergisi, 9, 176 -189.

Blanchard, R. A., Senesh, L. ve Patterson-Black, S. (1999). The organic social studies curriculum and the 1994 NCSS standards: A model for linking the community and the world. The Social Studies, 90(2). 63 -67.

Busby, R. S. (2011). Learning through doing: preservice teacher training in historical inquiry through oral history projects. The Oral History Review, 38(1), 1-10 doi: $10.1093 / \mathrm{ohr} / \mathrm{ohr} 048$

Büyüköztürk, Ş., K1lıç-Çakmak, E., Akgün, Ö. E., Karadeniz, Ş. ve Demirel, F. (2020). Eğitimde Bilimsel Araştırma Yöntemleri. (2. Bask1), Ankara: Pegem Yayınları.

Caunce, S. (2017). Sözlü tarih ve yerel tarihçi (3. Baskı, Çev. B.C. Bilmez ve A. Yalçınkaya). İstanbul: Tarih Vakfi Yurt Yayınları.

Creswell, J.W. (2016). Nitel Arştırma yöntemleri: Beş yaklaşıma göre nitel araştırma ve araştırma desenleri (3. Bask1, Çev. Ed. M. Bütün ve S.B. Demir). Ankara: Siyasal Kitabevi.

Crocco, M. S. (1998). Putting actors back on stage: oral history in the secondary school classroom. The Social Studies, 8(1), 19-24 DOI: 10.1080/00377999809599817

Çelik, H. (2018). Prospective social studies teachers' evaluations of their own oral history experiences related to Turkey's recent history. Journal of Education and Training Studies, 6(10), 123 -132 doi:10.11114/jets.v6i10.3457

Çelikkaya, T. ve Kuş, Z. (2009). Sosyal bilgiler öğretmenlerinin kullandıkları yöntem ve teknikler. Uludă̆ Üniversitesi Eğitim Fakültesi Dergisi, 22(2), 741-758.

Dayton-Wood, A., Hammonds, L., Matherson, L. ve Tollison, L. (2012). Bridging gaps and preserving memories through oral history, research and writing. English Journal, 101(4), $77-82$.

Demircioğlu, E. (2016). Teacher candidates' attitudes to using oral history in history education. Journal of Education and Training Studies, 4(6), 184 -191.

Demircioğlu, İ. H. (2007). Tarih ögretiminde öğrenci merkezli yaklaşımlar. (2.Bask1), Ankara: An1 Yayınc1lı. . 
Dere, İ. ve Alkaya, S. (2017). Sosyal bilgiler derslerinde tıp tarihi konularının sözlü tarihle öğretimi. Tarih Kültür ve Sanat Araştırmaları Dergisi, 6(6), 504-522.

Dere, İ. ve Emeksever, A. (2018). Hayat bilgisi derslerinde sözlü tarihle kültürel mirasın öğretimi. Gelecek Vizyonlar Dergisi, 2(4), 40 -47.

Dere, İ. (2018). Sosyal bilgiler lisans eğitiminde sözlü tarih: örnek bir uygulama. International Online Journal of Educational Sciences, 10(3), 243-262 DOI: https://doi.org/10.15345/iojes.2018.03.016

Dere, İ. (2019). Sosyal bilgilerde sözlü tarih. T. Çelikkaya, Ç.Ö. Demirbaş, T. Yıldırım ve H. Yakar (Ed.) Yeni program ve ders içeriklerine göre sosyal bilgiler ögretimi II içinde (ss. 407 -431). Ankara: Pegem.

Dere, İ. ve Dinç, E. (2018). Yapılandırmacı bir öğrenme ve öğretme yöntemi olarak sözlü tarihin sosyal bilgiler derslerine entegrasyonu. İönü Üniversitesi Eğitim Fakültesi Dergisi, 19(2), 115-127 DOI: 10.17679/inuefd.335686

Dilek, D. (2002). Tarih derslerinde öğrenme ve düşünme gelişimi (2. Baskı), Ankara: Pegem Yayıncilik.

Doğan, Y. (2015). How should an efficient oral history interview process be conducted according to the views of pre-service teachers. Academic Journals, 10(8), $1097-1108$. DOI: $10.5897 / /$ ERR2014.1926

Dökmen, Ü. (2011). İletişim çatışmaları ve empati (46. Baskı), İstanbul: Sistem Yayıncılık.

Dutt-Doner, K. M., Allen, S. ve Campanaroa, K. (2016). Understanding the Impact of using oral histories in the classroom, The Social Studies, 107(6), 257-265.

Dündar, Ş. (2017). Sınıf öğretmeni adaylarının sosyal bilgiler dersinde bir öğretim yöntemi olarak sözlü tarih hakkındaki görüşleri. Illköğretim Online, 16(4), 1621-1643 DOI: 10.17051/ilkonline.2017.342981

Foster, S. J. ve Padgett, C. S. (1999). Authentic historical inquiry in the social studies classroom. The Clearing House, 72(6), pp. 357 -263.

Kabapınar, Y. ve İncegül, S. (2016). Değiş̧im ve süreklilik bağlamında oyun ve oyuncağa bakmak: Bir sözlü tarih çalışması. Turkish History Education Journal, 5(1), 74-96.

Kaya, R. ve Güven, A. (2012). İlköğretim yedinci sınıf öğrencilerinin sosyal bilgiler derslerinde tarih konularının işlenişi ve tarihin değeri ile ilgili görüşleri. Turkish Studies, 7(2), 675691.

Kyvig, D. E. ve Marty, M. A. (2000). Yanıbaşımızdaki tarih. (Çev. N. Özsoy). İstanbul: Tarih Vakfi Yurt Yayınları.

Lattimer, H. ve Kelly, M. (2013). Engaging Kenyan secondary students in an oral history project: Education as emancipation. International Journal of Educational Development, $33,476-486$.

MEB (2005). İlkögrretim sosyal bilgiler dersi öğretim programı ve kılavuzu (4-5. sinıflar). Talim ve Terbiye Kurulu Başkanlığı, Ankara: Devlet Kitapları Müdürlüğü.

MEB (2018). Sosyal bilgiler dersi ögretim programı (İlkokul ve Ortaokul 4, 5, 6 ve 7. sinıflar). Erişim adresi: http://mufredat.meb.gov.tr/ProgramDetay.aspx?PID=354

Metin, B. ve Öz, M. (2019). 8. sınıf T.C. İnkılap Tarihi ve Atatürkçülük dersi konularının anlatılmasında sözlü tarih metodunun kullanımına yönelik öğretmen görüşleri. Bilecik Şeyh Edebali Üniversitesi Sosyal Bilimler Enstitüsü Dergisi, 4(1), 1-20 DOİ: $10.33905 /$ bseusbed.560152 
Mutluer, C. (2013). Sosyal bilgiler programlarında yer alan beceriler hakkında sosyal bilgiler öğretmen görüşleri (İzmir Menemen örneği). Turkish Studies, 8(7), 355-362.

Neyzi, L. (2019). National education meets critical pedagogy: Teaching oral history in Turkey. The Oral History Review, 46(2), 380-400. doi: 10.1093/ohr/ohz010

Ng-A-Fook, N. ve Smith, B. (2017). Doing oral history education toward reconciliation, K.R. Llewellyn ve N. Ng-A-Fook (Ed.), Oral history and education: theories, dilemmas, and practices içinde (ss. 65-86), Palgrave Macmillan US. DOI 10.1057/978-1-349-95019-5_4

OHA (2014). Principles and best practices for oral history education (4-12) classroom guide. Erişim adresi: https://www.oralhistory.org/wp-content/uploads/2014/04/2013-411_Oral_ History_ClassroomGuide_Update_V2.pdf

Öztürkmen, A. (2002). Sözlü tarih: Yeni bir disiplinin cazibesi. Toplum ve Bilim, 91, 115 -121.

Patton, M. Q. (2018). Nitel Araştırma ve değerlendirme yöntemleri. (2. Bask1, Çev. Ed. M. Bütün, S.B. Demir). Ankara: Pegem Akademi.

Ritchie, D. A. (2015). Doing oral history, (3rd ed.). New York: Oxford University Press.

Ross, E. W., Mathison, S. ve Vinson, K. D. (2014). Social studies curriculum and teaching in the era of standardization. İçinde E. W. Ross (Ed) The social studies curriculum: Purposes, problems and possibilities. (4. Bask1, ss. 25-49). Albany: State University of New York Press.

Safran, M. (2015). Sosyal bilgiler öğretimine bakış. İçinde B. Tay ve A. Öcal (Ed), Özel ögretim yöntemleriyle sosyal bilgiler ögrretimi. (4. Bask1, ss.1-15). Ankara: Pegem Akademi.

Sarı, İ. (2007). Sosyal bilgiler ögretiminde sözlü tarih etkinliklerinin ögrenci başarı, beceri ve tutumlarına etkisi. (Yayımlanmamış Doktora Tezi). Gazi Üniversitesi, Eğitim Bilimleri Enstitüsü, Ankara.

Sarı, İ. ve Türküresin-Er, H. (2018). A phenomenological study on the role of oral history practices in value education. International Journal of Eurasia Social Sciences, 9 (34). 2150-2179.

Somersan, S. (1998). Sözlü tarih, araştırmacılık ve tarih yazımına katılım, İçinde S. Özbaran, (Ed.). Tarih ögretimi ve ders kitapları (ss.381-392). İzmir: Dokuz Eylül.

Stradling, R. (2003). 20. yüzyll Avrupa tarihi nasıl öğretilmeli (Çev. A. Ünal). İstanbul: Türkiye Ekonomik ve Toplumsal Tarih Vakfi.

Şimşek, A. ve Kaymakçı, S. (2015). Okul dışı sosyal bilgiler öğretiminin amacı ve kapsamı. İçinde A. Şimşek, ve S. Kaymakçı, (Ed.), Okul dışı sosyal bilgiler ögretimi (ss. 1-14). Ankara: Pegem Akademi.

Thompson, P. (1999). Geçmişin sesi (Çev, Layıkel, Ş.). İstanbul: Tarih Vakfı Yurt Yayınları.

Welton, D. ve Mallan, T. (1988). Children and their world: strategies for teaching social studies. Boston: Houghton Mifflin.

Whitman, G. (2000). Teaching students how to be historians: An oral history project for the secondary school classroom, The History Teacher, 33(4), 469-481.

Yıldırım, A. ve Şimşek, H. (2018). Sosyal bilimlerde nitel araştırma yöntemleri. (11. Bask1). Ankara: Seçkin Yayıncılık.

Yin, R. K. (2014). Case study research design and methods (5th. Ed.) Thousand Oaks, CA: Sage. 
Yüksek Öğretim Kurumu (2018). Sosyal bilgiler öğretmenliği lisans programı. Erişim adresi: https://www.yok.gov.tr/Documents/Kurumsal/egitim_ogretim_dairesi/Yeni-OgretmenYetistirme-LisansProgramlari/Sosyal_Bilgileri_Ogretmenligi_Lisans_Programi0904201 9. pdf

\section{EXTENDED ABSTRACT}

\section{Purpose and Significance}

It is important to implement effective teaching methods in social studies courses, which are considered important for preparing young people for life and are included in the education programs of many countries. These courses contribute to the upbringing of current and equipped individuals. The oral history method, which contributes to meaningful and lasting learning of historical topics as well as significantly supports the development of skills in the social studies teaching program, attracts great attention today. Many countries have included this method into history and social sciences teaching programs. Although oral history has been incorporated into primary and secondary education curricula in Turkey for the last fifteen years, it was not seriously addressed in teacher education until recently. Research shows that teachers are not adequately familiar with oral history and it is not widely used at schools. Achieving the anticipated benefit of oral history in education is possible with well-organized activities. Therefore, the educator must have basic knowledge of conducting oral history work. It is known that until recently only a limited number of faculties of education in Turkey provided elective oral history courses at the undergraduate level. The social studies teaching undergraduate program, which was first offered in the 2018-2019 academic year, gives important opportunities for the development of knowledge and skills for teacher candidates in oral history studies thanks to new elective field courses. The researcher presumed that the teacher candidates' in-person experiencing of the oral history activity implementation process and objectives would have positive repurcussions on their teaching life and that the findings of a study would provide significant contributions to the oral history literature. Therefore, a model oral history activity was carried out within the scope of the course of historical evidence, local, and oral history in social studies teaching given by the researcher.

The aim of this research is to examine the views of social studies teacher candidates as regards the objectives of a model oral history activity carried out within the scope of the course of historical evidence, local, and oral history in the teaching of social studies. Based on this, answers were sought for the following questions:

1. What are the opinions of social studies teacher candidates about the general objectives of an oral history activity?

2. What are the opinions of social studies teacher candidates about the effects of the oral history activity on historical learning and historical thinking?

\section{Methodology}

A holistic single-case design, a qualitative research design, was used for the purposes of the study. The research group was determined in accordance with the convenience sampling method. The study group was comprised of a total of 18 volunteer teacher candidates, 11 female and 5 male, who attended the "historical evidence, local and oral history in social studies teaching" field education elective course given by the researcher during the 2019-2020 academic year at the Department of Social Studies Teaching, Faculty of Education, Ege University. Within the scope of the research, a project study themed "Being an Ege University Student in the 1970s" was carried out with the three-strong study groups voluntarily formed by the teacher candidates in accordance with the content of the course. Within the scope of the application, the participants were asked to conduct oral history interviews with at least 4 people, 
who studied at Ege University in the 1970s. An oral history practice guide prepared by the researcher based on the principles of the Oral History Association guided the teacher candidates in their work. The responsibilities of teacher candidates within the scope of this project was to perform preliminary research on the subject, contact the resource persons by their own means and perform interviews, record the interviews and label them in accordance with archiving, decipher the interview records and transcribe them, provide evidence of historical material from the interviewees, and present their work in a report. In the project reports, it was requested to give information about the oral history approach, to convey the group work plan and the experiences in the project process, to give information about the university life in the 1970s with the information synthesized from other sources and the statements of the source people, and to compare the period with the present. Teacher candidates were also asked to make inferences about the contributions of oral history study in the project report. On the other hand, teacher candidates were asked to record their experiences, thoughts, and feelings in the project process in diary format in the notebooks provided to them. At the end of the project, focus group meetings were held with the participants. The data collection phase of the research was planned to cover an 8-week process. The research was carried out on the basis of the volunteering of teacher candidates and upon the approval of the scientific research and publication ethics board of the relevant university. The data of the study were obtained from the relevant sections in teacher candidates' project reports, diaries, in which they recorded their experiences and thoughts during the process, and focus group interviews conducted through semi-structured interview forms. The data were evaluated according to content analysis, one of the qualitative data analysis methods. It was aimed to increase the validity and reliability of the research by using data diversification and participant confirmation strategies.

\section{Results, Discussion and Conclusion}

In order to find an answer to the first question of the study, the objectives as stated by the teacher candidates were coded and grouped under academic, personal, and social development categories. When ranked from top to bottom according to the number of frequencies, the personal objectives that emerged in line with the opinions of the teacher candidates were, respectively, the communication skills; empathy; gaining different perspectives; learning to be patient; critical thinking; sense of responsibility; self-control; and increase in self-confidence. Achievements in the academic development category were learning the research topic; learning oral history activity; contributing to professional development; having knowledge about scientific research; and writing skills with a keyboard/coordination. Social development objectives were listed as meeting new people; recognition and awareness of the environment and campus; and development of a sense of belonging to the university.

When the opinions of the teacher candidates were examined in terms of learning historical topics and the effect of the oral history study on historical thinking, all of the participants stated that they learned the research topic very well and they were able to develop historical empathy. The effect of oral history on gaining multiple perspectives by defining change and continuity showed a rather high frequency. Further findings in this section included thinking about the future; obtaining information that cannot be found in textbooks and written materials; ensuring the concretization of the learned information and increasing its permanence; to be able to view the subject from a wider spectrum; questioning one's own awareness about today, and rise of the desire to research the subject further.

The findings of the research are consistent with studies examining oral history practices carried out in various levels of education in Turkey and throughout the world. As a result, the oral history project carried out by the social studies teacher candidates within the scope of the course provided important personal objectives such as communication, empathy, critical thinking, and gaining different perspectives, as well as learning the basic principles of oral history study, while at the same time providing them with an idea of how to conduct scientific research. The teacher candidates discovered that the study of oral history was a powerful tool 
that increased effective, versatile, and permanent learning in teaching historical topics. This research has provided important findings that experiencing oral history activity during the undergraduate education may encourage teacher candidates to use this method in their professional lives. Selection of local history topics (the community, where students belong) in the oral history activity contributed significantly to historical empathy, defining change and continuity, raising awareness about the immediate environment, developing a sense of belonging to the community, and especially questioning our present and encouraging them to think about the future. It has been observed that this research about local history has increased the interest in a historical period and general events. Based on the results of the study, it is suggested that general classroom teachers, social studies teachers, and history teacher candidates be given the opportunity to experience oral history activities during undergraduate education with an aim to encourage teachers to use the oral history method more frequently at schools. On the other hand, it is important for teachers to learn the oral history method practically through in-service training programs in cooperation with universities and national education directorates. 